\title{
Motion guided segmentation of the right ventricle for 3D cine DENSE MRI
}

\author{
Andrew D Gilliam ${ }^{1 *}$, Frederick H Epstein ${ }^{2,3}$ \\ From 16th Annual SCMR Scientific Sessions \\ San Francisco, CA, USA. 31 January - 3 February 2013
}

\section{Background}

Cine displacement encoding with stimulated echoes (DENSE) provides quantitative imaging of tissue motion with high spatial resolution. Recent results have demonstrated that 3D cine DENSE provides resolution sufficient to quantify the mechanics of the right ventricle (RV) [1]. However, RV analysis currently requires manual anatomical delineation on all cine frames. This research extends motion guided segmentation methods [2,3] to the RV, requiring manual delineation of anatomy on only a single cine frame.

\section{Methods}

Five healthy volunteers were imaged using a 3D cine DENSE CMR protocol on a $1.5 \mathrm{~T}$ MR system (Avanto, Siemens). Imaging was performed with informed consent and in accordance with protocols approved by our Institutional Review Board.

DENSE observes tissue displacement at fixed voxels through which the underlying tissue moves. Each phase observation is proportional to a displacement indicating the initial location of underlying tissue when DENSE encoding occurred. Large phase values are wrapped to the intrinsic phase range of $[-\pi, \pi]$. Voxels empty of tissue contain unpredictable phase information.

Our solution propagated user-defined end-systolic RV anatomy through the multi-phase image series, using displacement guidance provided by DENSE observations. Voxels crossed by the end-systolic RV surface were identified, phase wrapping artifacts were corrected via a quality guided path following algorithm, and the RV was projected to its initial configuration via $3 \mathrm{D}$ radial basis function (RBF) interpolation. On each frame, we predicted the current RV configuration according to a linear motion model, unwrapped DENSE observations consistent with

${ }^{1}$ A.D. Gilliam Consulting, Providence, RI, USA

Full list of author information is available at the end of the article neighboring predictions, and estimated the true RV configuration from unwrapped observations via $3 \mathrm{D}$ RBF interpolation.

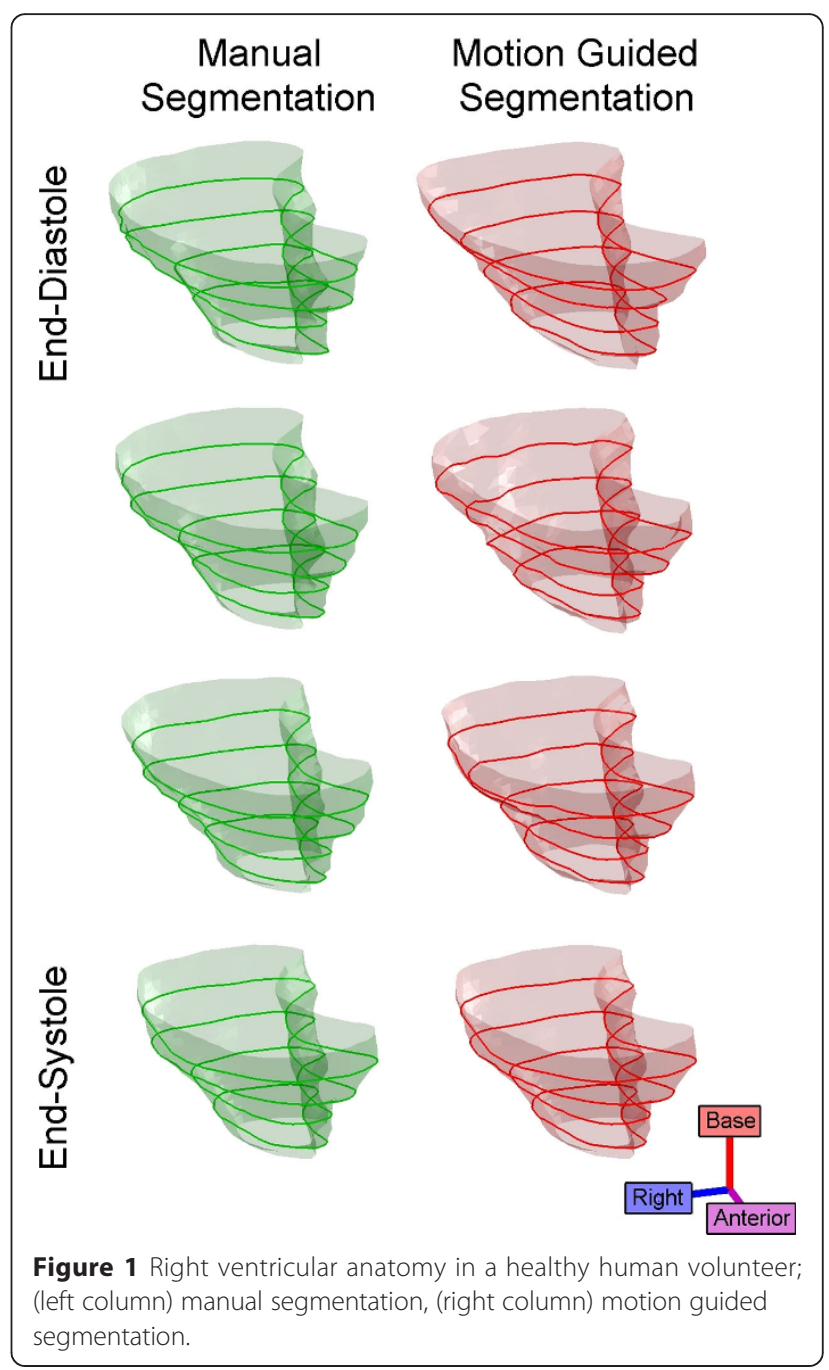

C Biomed Central

( 2013 Gilliam and Epstein; licensee BioMed Central Ltd. This is an Open Access article distributed under the terms of the Creative Commons Attribution License (http://creativecommons.org/licenses/by/2.0), which permits unrestricted use, distribution, and reproduction in any medium, provided the original work is properly cited. 


\section{Results}

Anatomy was manually delineated on all frames of all datasets for comparison. Fig. 1 illustrates a typical motion guided segmentation result compared to manual. Automatically guided segmentations achieved a root mean square distance of $1.73 \mathrm{~mm}$ to manual segmentations, with $92 \%$ of points on the guided segmentation surfaces within one pixel of manual segmentation surfaces.

\section{Conclusions}

This research presents the first motion guided segmentation algorithm specific to the RV for 3D cine DENSE CMR. This method promises to substantially reduce the time required for strain analysis of the RV. Guided segmentation results agreed well with manual RV delineation. Ongoing work seeks to further refine the automation process, perhaps eliminating the need for user-defined anatomy entirely.

\section{Funding}

Supported in part by NIH R01 EB 001763, Siemens, and AHA 12GRNT12050301.

\section{Author details}

${ }^{1}$ A.D. Gilliam Consulting, Providence, RI, USA. ${ }^{2}$ Biomedical Engineering, University of Virginia, Charlottesville, VA, USA. ${ }^{3}$ Radiology, University of Virginia, Charlottesville, VA, USA.

Published: 30 January 2013

\section{References}

1. Auger D, et al:. JCMR 2012, 14.

2. Spottiswoode B, et al:. Med Image Analysis 2009, 13.

3. Gilliam A, Epstein F.. IEEE T Med Imaging 2012, 31.

doi:10.1186/1532-429X-15-S1-P82

Cite this article as: Gilliam and Epstein: Motion guided segmentation of the right ventricle for 3D cine DENSE MRI. Journal of Cardiovascular Magnetic Resonance 2013 15(Suppl 1):P82.

\section{Submit your next manuscript to BioMed Central} and take full advantage of:

- Convenient online submission

- Thorough peer review

- No space constraints or color figure charges

- Immediate publication on acceptance

- Inclusion in PubMed, CAS, Scopus and Google Scholar

- Research which is freely available for redistribution

Submit your manuscript at www.biomedcentral.com/submit
C Biomed Central 